\title{
Farmers' Knowledge and Management of Rice Diseases in Uganda
}

\author{
Stella E. Adur-Okello ${ }^{1}$, Simon Alibu ${ }^{1}$, Jimmy Lamo ${ }^{1}$, Moses Ekobu ${ }^{1} \&$ Michael H. Otim ${ }^{1}$ \\ ${ }^{1}$ National Crops Resources Research Institute, Namulonge, Kampala, Uganda \\ Correspondence: Stella E. Adur-Okello, National Crops Resources Research Institute, Namulonge, P.O. Box \\ 7084, Kampala, Uganda. Tel: 256-772-375-527. E-mail: seokello@gmail.com
}

Received: March 16, 2018

doi:10.5539/jas.v12n12p221
Accepted: April 27, $2020 \quad$ Online Published: November 15, 2020

URL: https://doi.org/10.5539/jas.v12n12p221

\begin{abstract}
Rice in the recent past has picked up as a food security and income generating crop among farming households in Uganda. Even though, the crop is playing a significant role in reducing food insecurity and poverty within the country, its productivity has remained constant and low at about 1.5 metric tonnes per hectare. Using cross-sectional data collected from rice farmers in Northern (Lira, Dokolo, Otuke and Alebtong Districts); Eastern (Iganga, Bugiri and Kamuli Districts) and Central (Kayunga District) regions of the country, this paper establishes farmers' knowledge and management of rice diseases from a total of 224 farmers, as a baseline for research initiatives focusing on improving rice productivity within the country. Farmers ranked diseases as the second most important constraint in rice production, after insect pests. Moreover, farmers ranked rice yellow mottle virus (RYMV) as the most important disease in rice production, followed by leaf blast (LB), brown spot (BS), sheath rot (ShR), panicle blast (PB) and bacterial leaf blight (BLB). However, $60 \%$ of farmers identified RYMV while less than $30 \%$ could clearly diagnose the symptoms of each of the other diseases. Surprisingly, only about $18 \%$ of farmers employed management options against RYMV, whereas less than $6 \%$ practiced some form of management for each of the other major diseases. The predominant disease control measure was uprooting diseased plants followed by insecticide application. About $10 \%$ of farmers reported sedges (Cyperus spp.), goat weed (Ageratum conyzoides), black jack (Bidens pilosa), and cut grass (Leersia spp.) as alternative host plants for rice diseases. An integrated disease management approach, whose development and implementation recognizes farmers as the key players in the rice production chain, is required to achieve improved and sustainable rice productivity.
\end{abstract}

Key words: alternative hosts, diseases, knowledge, management, Uganda

\section{Introduction}

Rice crop is attacked by a number of diseases, some of which cause serious economic losses while others are of minor importance (Mississippi State University, 2001). The diseases are caused by various pathogens such as viruses, bacteria, fungi, nematodes (Safdar, Salahuddin, \& Chaudhary, 1993). These pathogens may appear at any growth stage and or on part of the plant, including the seed, root system, foliage, stalk, leaf sheath, inflorescence and the grain (Government of Sindh-Agriculture Department, 2004). Uganda, like other rice growing countries, has made advances in the development of disease resistant rice varieties. However, the impact of diseases on rice production has increased over time. This is because there are limitations in the usage of only resistant varieties to manage rice diseases. Most improved varieties exude appreciable resistance to a few major diseases that are the subject of intensive breeding (Youyong, 2006). The rice production environments, particularly in the tropics, are habitats of many rice pathogens causing varying degrees of damage (Mew, 1992).

Mississippi State University (2001), noted that diseases have become more important in rice production, due to expanded acreage, prolonged re-cropping of fields and limited land for long rotations in most rice growing countries. In Uganda, the total area under rice cultivation increased from 39,000 $\mathrm{Ha}$ in 1990 to $140,000 \mathrm{Ha}$ in 2010 (Ahmed, 2012). The rapid increase in area under rice production is greatly attributed to initiatives that focused on: (a) improving rice productivity through the introduction of improved rice varieties such as New Rice for Africa (NERICA) (b) mass promotion and dissemination of upland rice varieties among smallholder farmers, as a key household income generating crop in 2004. The latter was with lead support from UNDP (United Nations Development Programme) joined by USAID (United States Agency for International Development), FAO (Food and Agriculture Organization), JICA (Japan International Cooperation Agency), DANIDA (Danish International Development Agency), SG2000 (Sasakawa Africa Association) and NARO (National Agricultural 
Research Organization) (Odogola, 2006). These initiatives resulted into the growth and rapid expansion of rice production in the upland ecology, yet initially, rice was a crop adapted only to lowland ecologies. The initiation of rice production into the upland ecology makes it important to pay attention to biotic constraints like diseases, weeds, pests and rodents, which impinge on the productivity of rice crop.

According to Youyong (2006), diseases have been a major cause of yield loss and lower profits in rice production, with annual estimated yield and quality losses of $8-10 \%$ in rice growing countries. Production costs have also increased owing to the use of chemical and cultural methods of disease control. The type and seriousness of particular rice diseases is often determined by the management practices used plus patterns of rice variety usage among different farms and geographic regions. Correct disease diagnosis is essential for both economic justification for treatment and protection against crop failure. Proper identification of diseases is the first step in rice disease management. Some diseases can be managed by simply changing or adopting new cultural practices or by selecting a resistant variety (Mwalyego \& Kayeke, 2011). Rice diseases are mainly identified by symptoms because each disease has unique characteristics that distinguish it from the other diseases. However, a farmer can only benefit from application of management options if a disease is damaging, not a minor.

Recent development initiatives in Uganda' rice industry, including the East African Agricultural Productivity Program phase 1 (2011 to 2016) emphasized the need to generate basic information on farmers' knowledge and management of rice pests and diseases as a basis for guiding research initiatives on rice productivity improvement. Documenting farmers' knowledge and management of rice diseases is important in guiding development of sustainable rice crop technologies, whose adoption will trigger improved productivity, food security and income of the farming households.

\section{Materials and Methods}

\subsection{Study Area and Sampling}

The study is based on cross-sectional data that was collected through a household survey conducted from Northern, Eastern and Central regions of the country. This survey covered 4 districts (Lira, Dokolo, Otuke and Alebtong) in Northern Uganda, 3 districts (Iganga, Bugiri and Kamuli) in Eastern; and one district (Kayunga) in central region. More districts were selected from Northern and Eastern because these regions have been involved in rice production, especially under lowland rainfed and irrigated ecologies since the 1950s. Central region only started growing rice recently, under upland ecology because of the productivity and promotional initiatives for rice crop. From each district, one main rice producing sub-county was randomly selected, while three main rice producing parishes were randomly selected from each sub-county. Ten (10) households were also randomly drawn from each parish, making a total of 240 households as respondents. However, as shown in Table 1, two hundred twenty four (224) households were used in the analysis because responses from 16 were incomplete. 
Table 1. Number of households by location

\begin{tabular}{|c|c|c|c|c|c|c|}
\hline Region & District & Sub-county & Parishes & Sample/parish & Sample/District & Sample/Region \\
\hline \multirow{12}{*}{ Northern } & & & Onywako & 10 & & \multirow{12}{*}{113} \\
\hline & Lira & Barr & Olilo & 12 & 30 & \\
\hline & & & Alebere & 8 & & \\
\hline & & & Adwoki & 10 & & \\
\hline & Dokolo & Agwata & Amuda & 8 & 27 & \\
\hline & & & Adok & 9 & & \\
\hline & & & Barocok & 10 & & \\
\hline & Otuke & Okwang & Olwor-ngu & 9 & 30 & \\
\hline & & & Opejal & 11 & & \\
\hline & & & Obim & 10 & & \\
\hline & Alebtong & Apala & Abia & 8 & 26 & \\
\hline & & & Aberidwongomera & 8 & & \\
\hline \multirow{9}{*}{ Eastern } & & & Nabubya & 9 & & \multirow{9}{*}{85} \\
\hline & Iganga & Bukanga & Buwologoma & 11 & 29 & \\
\hline & & & Namukubembe & 9 & & \\
\hline & & & Lwanka & 6 & & \\
\hline & Bugiri & Nabukalu & Isegero & 20 & 30 & \\
\hline & & & Kasita & 4 & & \\
\hline & & & Butansi & 10 & & \\
\hline & Kamuli & Butansi & Naluwoli & 8 & 26 & \\
\hline & & & Naibowa & 8 & & \\
\hline \multirow{3}{*}{ Central } & & & Kigayaza & 19 & & \multirow{3}{*}{26} \\
\hline & Kayunga & Kangulumira & Kikwanya & 4 & 26 & \\
\hline & & & Kangulumira & 3 & & \\
\hline Total & & & & & 224 & 224 \\
\hline
\end{tabular}

\subsection{Methods}

In each sampled household, the member that was most involved in rice production was sought and interviewed using a semi-structured questionnaire that was developed by a multi-disciplinary team comprising of Breeders, Entomologists, Agronomists and Socio-economists. Household heads or their spouses were the most involved in rice production, represented by $76 \%$ and $24 \%$, respectively, as respondents.

The data collection team was trained on the questionnaire and pre-testing was done in Luwero District before executing the actual data collection. The pre-tested questionnaire was reviewed based on feedback so as to make it effective to address the study objectives as well as ensure smooth flow of the interview process.

The questionnaire covered farmer's age, level of education, land holding, experience in rice farming, rice production constraints, rice diseases including symptom description, control measures and perception on the level of effectiveness of the measures. The questionnaire also included farmers' observation of rice diseases on other plants/vegetation (alternative host plants of rice diseases).

Pictorial illustrations were used by enumerators to identify rice diseases as the respondents/farmers described the respective diseases symptoms.

The data was coded and entered into a data template in MS Excel. Data analysis was executed in STATA Version 11 to generate frequencies and percentages for socio-economic characteristics of the farmers, disease description and management. The order of importance of production constraints and rice diseases was determined using a weighting score. This score involved multiplying the frequency of responses for a particular variable rank with the respective weight and summing up the weight of each rank for the variable (be it constraint or disease) to get its total weight. For instance, production constraints were ranked up to 5 most important. Weights of 5, 4, 3, 2 and 1 were multiplied with frequency of responses for each constraint ranked as $1,2,3,4$ and 5 respectively to determine the weight for specific rank order of the constraint. The weight for each constraint rank order was added to give the total weight of the constraint. The constraint with the highest total weight was considered the most important. 


\section{Results}

\subsection{Farmers' Characteristics}

The characteristics of the farmers are summarized in Table 2. Eighty eight (88\%) percent of the farmers were males. Although only $12 \%$ of these farmers were females, they were distributed across all the three regions of the country. The educational level of these farmers varied with $60 \%$ attaining primary level education, followed by $30 \%$ with secondary education and only $1 \%$ attaining college/university level education. Farmers with no formal education were mainly from Northern and Eastern region. The mean age of these farmers was 41years even though $30 \%$ and $25 \%$ of them respectively fell within the age bracket of $31-40$ years and $41-50$ years.

Table 2. Farmers' characteristics by region

\begin{tabular}{|c|c|c|c|c|}
\hline Characteristic of the farmer/household head & All regions & Northern region & Eastern region & Central region \\
\hline \multicolumn{5}{|l|}{ Sex of the farmer } \\
\hline Male headed (\%) & 88 & 89 & 91 & 73 \\
\hline Female headed $(\%)$ & 12 & 11 & 9 & 27 \\
\hline \multicolumn{5}{|l|}{ Education } \\
\hline No formal education $(\%)$ & 9 & 6 & 11 & 12 \\
\hline Primary education (\%) & 60 & 55 & 66 & 65 \\
\hline Secondary education (\%) & 30 & 37 & 22 & 23 \\
\hline University (\%) & 1 & 2 & 1 & 0 \\
\hline \multicolumn{5}{|l|}{ Age } \\
\hline Mean age (years) & 41.0 & 40.8 & 41.4 & 40.7 \\
\hline 20 years \& less $(\%)$ & 2 & 3 & 1 & 0 \\
\hline $21-30$ years $(\%)$ & 21 & 21 & 24 & 15 \\
\hline $31-40$ years $(\%)$ & 30 & 34 & 25 & 35 \\
\hline $41-50$ years $(\%)$ & 25 & 19 & 31 & 31 \\
\hline $51-60$ years $(\%)$ & 16 & 18 & 13 & 19 \\
\hline $61-70$ years $(\%)$ & 5 & 5 & 6 & 0 \\
\hline Above 70 years $(\%)$ & 1 & 1 & 1 & 0 \\
\hline
\end{tabular}

\subsection{Farm Characteristics}

Generally, the mean number of years of experience in farming was 20 years. A majority (31\%) of farmers had farming experience of $11-20$ years, followed by $26 \%$ having experience of $1-10$ years (Table 3 ). Only $1 \%$ of farmers (all from Northern region) had experience in farming for a period over 50 years.

The mean number of years of experience in rice farming was 7.4 years. However, majority $(50 \%)$ of farmers had 1-5 years of experience in rice farming while $30 \%$ had produced rice for $6-10$ years. About $80 \%$ of farmers had grown rice for not more than 10years. Central region had the least experience in rice production in comparison to Northern and Eastern regions. No farmer from Central region had more than 10 years of experience in rice production whereas some farmers from Eastern and Northern regions respectively, had up to 30years and 50 years of experience in rice production.

The mean land holding was 6.1acres (Table 3). Farmers from Northern region had relatively large average land holding than Eastern and Central, as represented by mean acreage of 8.2, 7.2 and 3.7 acres respectively. Although the overall mean land holding was 6.1 acres, only $10 \%$ of these farmers owned more than 10acres of land, implying that a majority $(90 \%)$ were small land holders.

The main land use system for rice production was single cropping (growing rice once a year) as reported by $85 \%$ of the farmers. Double cropping (growing rice twice a year) was only practiced in Eastern and Central region of Uganda (Table 3). 
Table 3. Farm characteristics by region

\begin{tabular}{|c|c|c|c|c|}
\hline Characteristic & All regions & Northern region & Eastern region & Central region \\
\hline \multicolumn{5}{|l|}{ Experience in farming } \\
\hline Mean years of farming (years) & 19.7 & 19.3 & 19.5 & 22.2 \\
\hline Less than 1 year $(\%)$ & 4.0 & 4.4 & 3.5 & 3.8 \\
\hline $1-10$ years $(\%)$ & 25.9 & 29.2 & 24.7 & 15.4 \\
\hline $11-20$ years $(\%)$ & 31.3 & 30.1 & 31.8 & 34.6 \\
\hline $21-30$ years $(\%)$ & 20.5 & 13.3 & 29.4 & 23.1 \\
\hline $31-40$ years $(\%)$ & 13.4 & 16.8 & 5.9 & 23.1 \\
\hline $41-50$ years $(\%)$ & 4.5 & 5.3 & 4.7 & 0.0 \\
\hline Above 50 years $(\%)$ & 0.4 & 0.9 & 0.0 & 0.0 \\
\hline \multicolumn{5}{|l|}{ Experience in rice farming } \\
\hline Mean years of rice farming (years) & 7.4 & 6.8 & 9.4 & 3.1 \\
\hline Less than 1 year $(\%)$ & 1.3 & 2.7 & 0.0 & 0.0 \\
\hline $1-5$ years $(\%)$ & 50.0 & 48.7 & 38.8 & 92.3 \\
\hline $6-10$ years $(\%)$ & 30.0 & 32.7 & 34.1 & 7.7 \\
\hline $11-15$ years $(\%)$ & 8,5 & 11.5 & 7.1 & 0.0 \\
\hline $16-20$ years $(\%)$ & 4.9 & 2.7 & 9.4 & 0.0 \\
\hline $21-25$ years $(\%)$ & 1.3 & 0.0 & 3.5 & 0.0 \\
\hline $26-30$ years $(\%)$ & 2.7 & 0.9 & 5.9 & 0.0 \\
\hline $46-50$ years $(\%)$ & 0.4 & 0.9 & 0.0 & 0.0 \\
\hline Don't know (\%) & 0.4 & 0.0 & 1.2 & 0.0 \\
\hline \multicolumn{5}{|l|}{ Land holding } \\
\hline Mean land holding (acres) & 6.1 & 8.2 & 7.2 & 3.7 \\
\hline \multicolumn{5}{|l|}{ Rice production ecology } \\
\hline Upland (\%) & 10.3 & 0 & 1.2 & 84.6 \\
\hline Lowland (\%) & 89.7 & 100 & 98.8 & 15.4 \\
\hline \multicolumn{5}{|l|}{ Land use system for rice* } \\
\hline Double cropping (\%) & 13.2 & 0 & 29.4 & 11.5 \\
\hline Single cropping $(\%)$ & 85.2 & 97.3 & 68.2 & 80.8 \\
\hline Intermittent cropping ( $\%)$ & 1.6 & 2.7 & 2.4 & 7.7 \\
\hline
\end{tabular}

Note. *Double cropping-growing rice twice in a year; single cropping-producing rice only once a year and intermittent cropping-no defined cropping schedule.

\subsection{Rice Production Constraints}

Farmers ranked insect pests, diseases and weeds, in descending order, as the top three most important rice production constraints (Table 4). The other constraints in order of importance included financial constraints, birds, limited land and rodents. As shown in Table 4, five (insect pests, diseases, weeds, birds and rodents) of the first ten most important production constraints were biotic, four (financial limitation, land limitation, lack of chemical inputs and lack of quality seed seed) were socio-economic related constraints while only one (drought) was abiotic. This is an indication that biotic, abiotic and socio-economic factors are all important in rice production. Financial constraint was mainly associated with hiring labor for production activities to supplement family labor, tractor and ox-plough services. 
Table 4. Farmers' ranking of rice production constraints in order of importance

\begin{tabular}{lll}
\hline Constraints & Total weight & Rank/order of importance \\
\hline Insect pests & 522 & 1 \\
Diseases & 478 & 2 \\
Weeds & 391 & 3 \\
Financial constraint & 390 & 4 \\
Birds & 198 & 5 \\
Limited land & 186 & 6 \\
Rodents & 137 & 7 \\
Lack of chemical inputs & 99 & 8 \\
Drought & 95 & 9 \\
Lack of quality seed & 79 & 10 \\
Inadequate rice production implements & 79 & 10 \\
Unstable prices for rice & 68 & 12 \\
Labor shortage & 60 & 13 \\
Floods & 53 & 14 \\
Lack of knowledge in rice production & 43 & 15 \\
Rudimentary harvesting equipment & 38 & 16 \\
Transport problem & 31 & 17 \\
Low soil fertility & 21 & 18 \\
Lack of storage facilities & 14 & 19 \\
Poor water management system & 13 & 20 \\
\hline
\end{tabular}

\subsection{Rice Diseases}

The five diseases ranked as the most important in rice production, in order of importance, were rice yellow mottle virus (RYMV), leaf blast (LB), brown spot (BS), sheath rot (ShR) and panicle blast (PB) (Table 5). The other important diseases in descending order were bacterial leaf blight (BLB), false smut (FSM), sheath blight $(\mathrm{ShB})$, grain rot (GR) and leaf scale (LS). Based on the low weight recorded by neck blast (NB), bacterial leaf streak (BLS) and narrow leaf brown spot (NBS), they were the diseases considered as uncommon/rare in rice production by these farmers.

Rice diseases were broadly divided into five categories as foliar, tiller, panicle, grain and viral or systemic diseases (Table 5). The foliar categories dominated followed by viral, tiller, panicle and lastly grain categories. Among the foliar diseases, the most important was leaf blast followed by brown spot, bacterial leaf blight and leaf scale. With the exception of leaf scale, the top most important foliar diseases fell among the top six important diseases in the general ranking of diseases. The major tiller diseases were sheath rot and sheath blight while grain diseases were false smut and grain rot in descending order. The main panicle disease was the panicle blast. 
Table 5. Farmers' ranking of rice diseases by categories and order of importance

\begin{tabular}{|c|c|c|c|}
\hline Type of diseases & Diseases & Total weight & Rank \\
\hline \multirow{13}{*}{$\begin{array}{l}\text { All common diseases } \\
\text { (diseases affecting all parts of the rice plant) }\end{array}$} & Rice yellow mottle virus (RYMV) & 1554 & 1 \\
\hline & Leaf blast (LB) & 790 & 2 \\
\hline & Brown spot (BS) & 755 & 3 \\
\hline & Sheath rot (ShR) & 638 & 4 \\
\hline & Panicle blast (PB) & 591 & 5 \\
\hline & Bacterial leaf blight (BLB) & 428 & 6 \\
\hline & False smut (FSM) & 361 & 7 \\
\hline & Sheath blight (ShB) & 356 & 8 \\
\hline & Grain rot $(\mathrm{GR})$ & 223 & 9 \\
\hline & Leaf scald (LS) & 160 & 10 \\
\hline & Neck blast (NB) & 85 & 11 \\
\hline & Bacterial leaf streak (BLS) & 35 & 12 \\
\hline & Narrow leaf brown spot (NBS) & 23 & 13 \\
\hline Viral or systemic & Rice yellow mottle virus (RYMV) & 1554 & 1 \\
\hline \multirow{6}{*}{ Foliar diseases } & Leaf blast (LB) & 790 & 1 \\
\hline & Brown spot (BS) & 755 & 2 \\
\hline & Bacterial leaf blight (BLB) & 428 & 3 \\
\hline & Leaf scald (LS) & 160 & 4 \\
\hline & Bacterial leaf streak (BLS) & 35 & 5 \\
\hline & Narrow leaf brown spot (NBS) & 23 & 6 \\
\hline \multirow{2}{*}{ Tiller diseases } & Sheath rot $(\mathrm{ShR})$ & 638 & 1 \\
\hline & Sheath blight $(\mathrm{ShB})$ & 356 & 2 \\
\hline \multirow{2}{*}{ Panicle diseases } & Panicle blast (PB) & 591 & 1 \\
\hline & Neck blast (NB) & 85 & 2 \\
\hline \multirow{2}{*}{ Grain diseases } & False smut (FSM) & 361 & 1 \\
\hline & Grain rot (GR) & 223 & 2 \\
\hline
\end{tabular}

\subsection{Farmers' Knowledge of Rice Diseases}

Farmers expressed their knowledge of rice diseases by describing symptoms of the diseases (Figures 1 and 2) and the growth stages of rice plant at which the respective diseases were observed (Figure 3).

\subsubsection{Farmers' Description of Rice Disease Symptoms}

The most known disease was rice yellow mottle virus (RYMV), as $60 \%$ of the respondents were able to describe its symptoms (Figure 1). RYMV was followed by brown spot (BS), bacterial leaf blight (BLB) and leaf blast (LB) for which $29 \%, 27 \%$ and $26 \%$ of respondents, respectively, described their symptoms. The least known diseases were bacterial leaf streak (BLS) and narrow leaf brown spot (NBS), as each was described by only $1 \%$ of the responding farmers. This implies that RYMV, BS, BLB and LB are diseases of economic importance while BLS and NBS are minor diseases in rice production in Uganda.

Male farmers were more able to describe rice diseases than their female counterparts. Some diseases were distinctively described by only male farmers. These diseases included bacterial leaf blight, bacterial leaf streak, narrow leaf brown spot and panicle blast. Only $3.7 \%$ of the female farmers could clearly describe the symptoms of leaf blast, brown spot, sheath rot, sheath blight, false smut, neck blast, grain rot and leaf scald. However, rice yellow mottle virus, perceived by the farmers as the most important disease could be described by only $11 \%$ of the women farmers. 


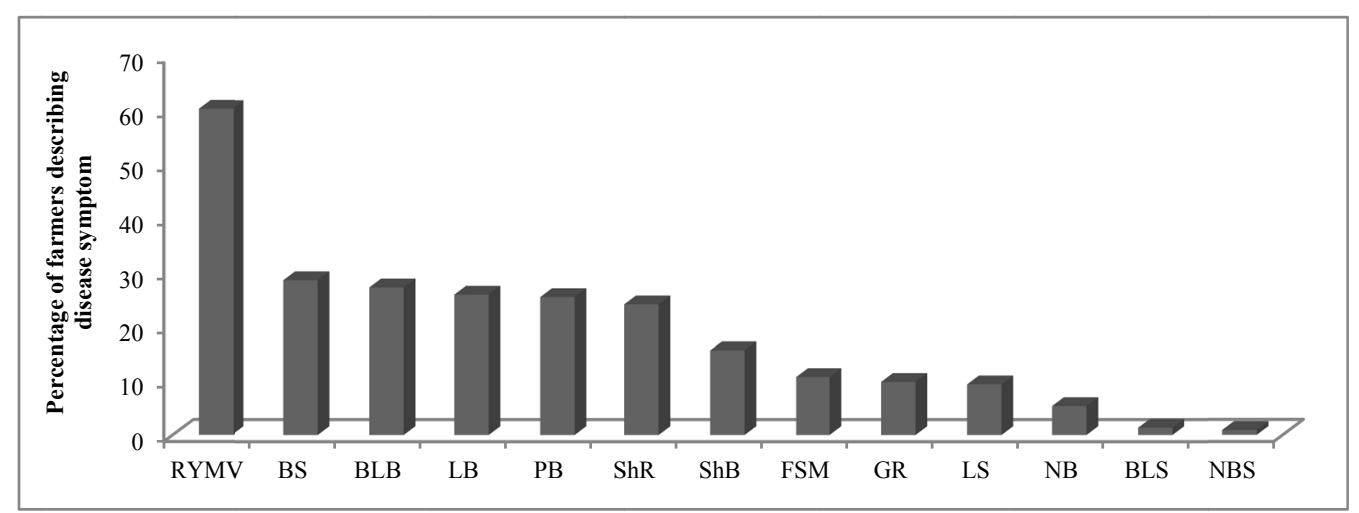

Figure 1. Percentage of farmers that could describe specific rice disease symptoms

Note. RYMV = Rice yellow mottle virus, $\mathrm{BS}=$ Brown spot, $\mathrm{BLB}=$ Bacterial leaf blight, $\mathrm{LB}=$ Leaf blast, $\mathrm{PB}=$ Panicle blast, $\mathrm{ShR}=$ Sheath rot, $\mathrm{ShB}=$ Sheath blight, $\mathrm{FSM}=$ False smut, $\mathrm{GR}=$ Grain rot, $\mathrm{LS}=$ Leaf scale, $\mathrm{NB}=$ Neck blast, $\mathrm{BLS}=$ Bacterial leaf streak, NBS $=$ Narrow leaf brown spot.

Each of the rice diseases was described by specific symptoms as presented in Figure 2. Some of the diseases were described by more than one symptom. These included RYMV, PB, ShB, LS, BS, LB and BLB. The most known disease, RYMV was predominantly described by $52 \%$ of farmers as bearing the symptom of yellowing of the plant. Brown spot (BS) was mainly mentioned by $26 \%$ of farmers as showing numerous brown spots on leaves of rice plant. Sheath rot (ShR), on the other hand, was reported as having the symptom of rotten sheath by $24 \%$ of farmers, while panicle blast's sign of black grains with unfilled panicles was described by $18 \%$ of farmers. Apart from the above, leaf blast was noted by $15 \%$ of respondents as showing brown blotches/dots on leaves, whereas false smut (FSM) was recorded by $11 \%$ as bearing black powdery and swollen grains. Bacterial leaf blight was reported as carrying the symptoms of leaves drying from the mid ribs by $10 \%$ of respondents and leaves having lesions from the tips and sides also by $10 \%$ of the farmers.

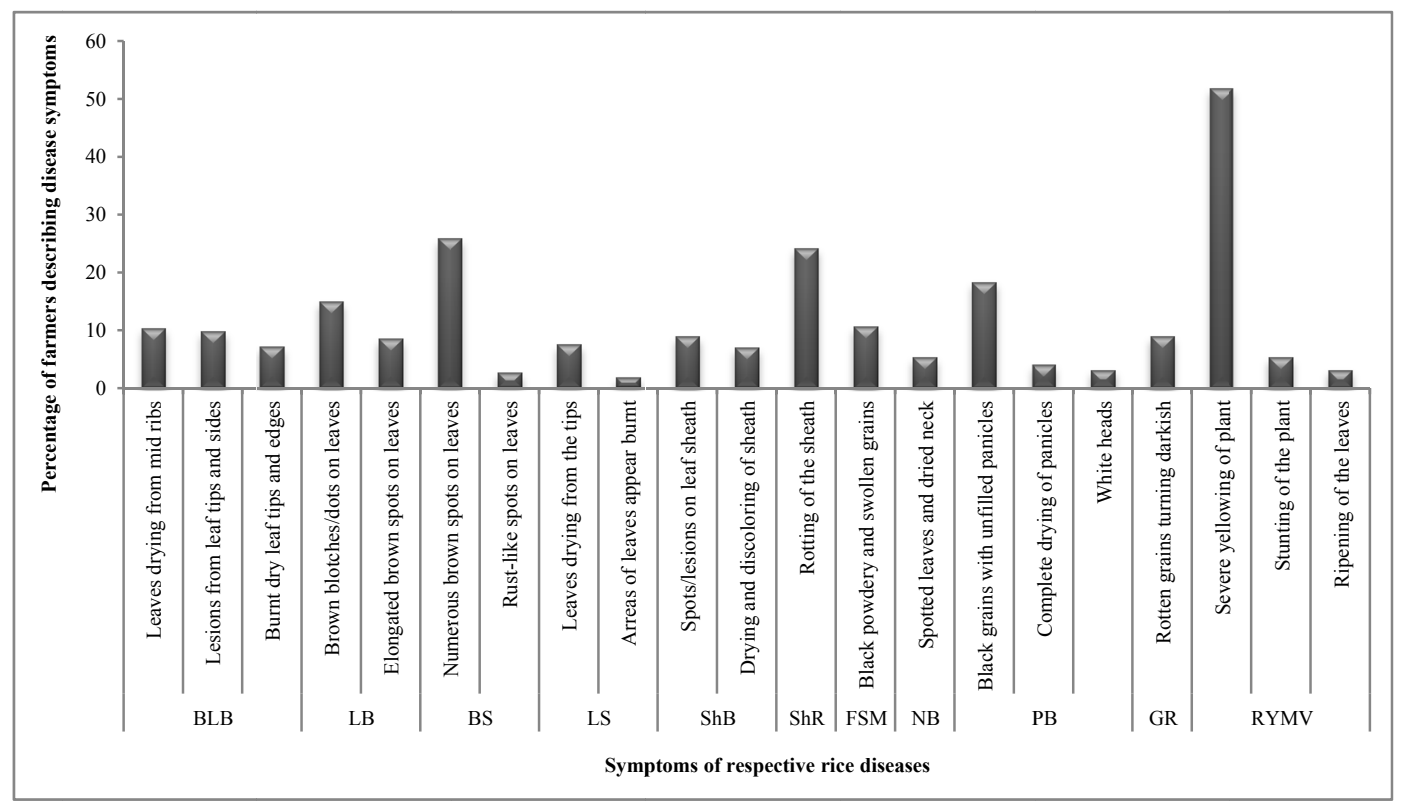

Figure 2. Percentage of farmers who described specific symptom of rice diseases

Note. BLS and NBS excluded from the graph because each was described by only $1 \%$ of respondents.

$\mathrm{RYMV}=$ Rice yellow mottle virus, $\mathrm{BS}=$ Brown spot, $\mathrm{BLB}=$ Bacterial leaf blight, $\mathrm{LB}=$ Leaf blast, $\mathrm{PB}=$ Panicle blast, $\mathrm{ShR}=$ Sheath rot, $\mathrm{ShB}=$ Sheath blight, FSM $=$ False smut, GR $=$ Grain rot, LS $=$ Leaf scale, NB = Neck blast, $\mathrm{BLS}=$ Bacterial leaf streak, NBS = Narrow leaf brown spot. 


\subsubsection{Farmers' Knowledge of Rice Growth Stages at Which Disease Symptoms Occurred}

Farmers provided information on distinctive growth stages of rice plant at which respective disease symptoms were frequently observed. Rice yellow mottle virus disease, bacterial leaf blight, brown spot, leaf blast and leaf scald were mainly reported to occur or manifest at tillering (Figure 3). Sheath rot and sheath blight were mostly observed at flowering while grain rot at heading. On the other hand, neck blast mainly occurred at booting, whereas panicle blast and false smut showed symptoms respectively at panicle initiation and dough growth stages.

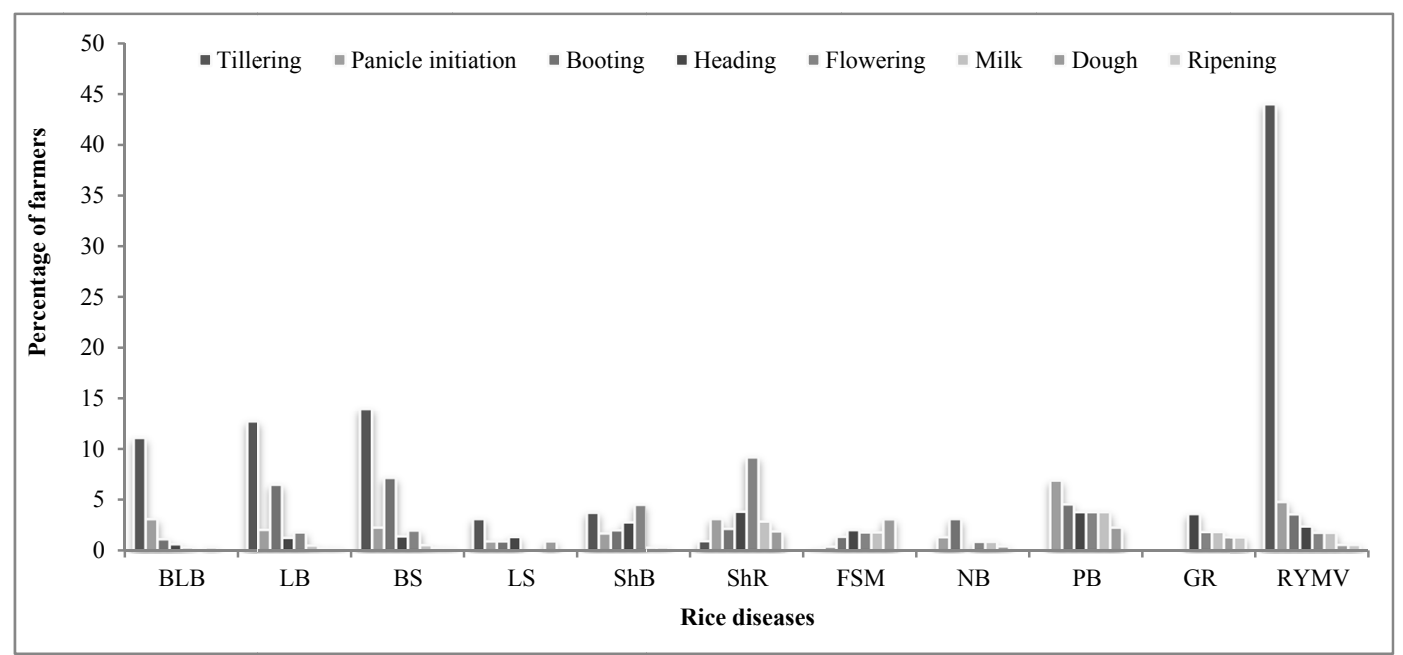

Figure 3. Percentage of farmers who noticed disease symptoms at different growth stages

Note. BLS and NBS excluded from the graph because each was described by only $1 \%$ of respondents.

$\mathrm{RYMV}=$ Rice yellow mottle virus, $\mathrm{BS}=$ Brown spot, $\mathrm{BLB}=$ Bacterial leaf blight, $\mathrm{LB}=$ Leaf blast, $\mathrm{PB}=$ Panicle blast, $\mathrm{ShR}=$ Sheath rot, $\mathrm{ShB}=$ Sheath blight, $\mathrm{FSM}=$ False smut, GR $=$ Grain rot, LS $=$ Leaf scale, NB = Neck blast, $\mathrm{BLS}=$ Bacterial leaf streak, NBS $=$ Narrow leaf brown spot.

\subsection{Farmers' Management of Rice Diseases}

The management practices employed by the rice farmers against diseases were: cultural methods (early sowing, destruction of wild rice, burning of rice stubble); chemical/insecticide application; use of improved varieties perceived to be resistant and agronomic practices (fallowing, adjusting fertilizer dosage and uprooting/roguing diseased plants). The most commonly used varieties that were perceived as resistant to major rice diseases were Nerica 4 and 1while the mostly used insecticides were Dursban (a.i. Chlorpyrifos) and Ambush (a.i. Cypermethrin). Based on farmers' ranking, the six major rice diseases were rice yellow mottle virus (RYMV), leaf blast (LB), brown spot (BS), sheath rot (ShR), panicle blast (PB) and bacterial leaf blight (BLB). The respective management practices employed against the top six important diseases are shown in Figure 4. Rice yellow mottle virus disease was identified by $60 \%$ of respondents yet only $17.9 \%$ (40 farmers) employed management options against it. The other diseases (LB, BS, ShR, PB and BLB) were each recognized by less than $30 \%$ of the farmers, and each of them was managed by less than $6 \%$ of the farmers. The most used management option against RYMV was uprooting diseased plants followed by insecticide application, adjusting fertilizer dosage and burning of rice stubble. The most used management practices against LB, BS and ShR was uprooting diseased plants, while that against PB was insecticide application and uprooting diseased plants. BLB was mainly managed by insecticide, uprooting diseased plants and burning of rice stubble. The use of improved varieties perceived to be resistant to diseases and destruction of wild rice were employed against only RYMV and BS. Early sowing and fallowing were only employed against RYMV. 


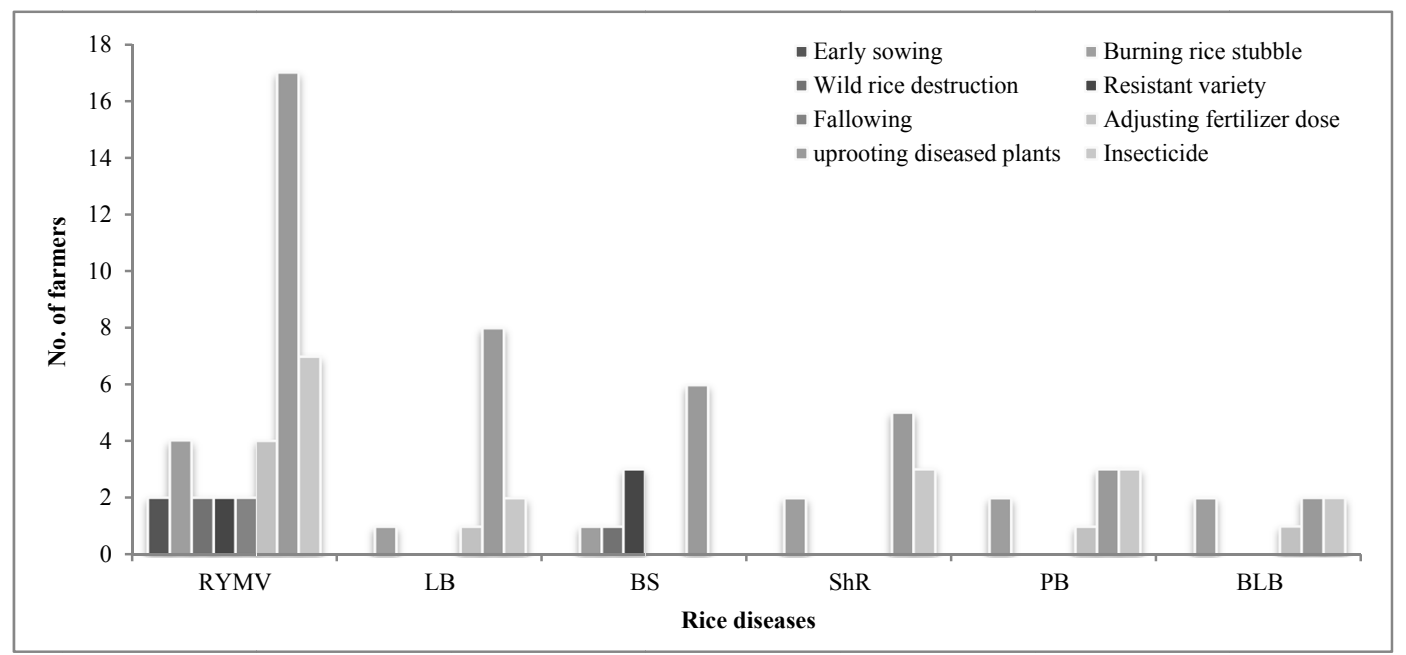

Figure 4. Management options employed by farmers on the major rice diseases

Note. $\mathrm{RYMV}=$ Rice yellow mottle virus, $\mathrm{LB}=$ Leaf blast, $\mathrm{BS}=$ Brown spot, $\mathrm{ShR}=$ Sheath rot, $\mathrm{PB}=$ Panicle blast, $\mathrm{BLB}=$ Bacterial leaf blight.

\subsection{Farmers' Perception of Effectiveness of Rice Disease Management Practices}

The perceived level of effectiveness of the management options employed by farmers against the six major rice diseases varied (Table 6). Uprooting diseased plants, insecticide use and burning of rice stubble were employed against all the six major diseases, and each was perceived as not effective, somewhat effective, effective and indifferent by the farmers. Early sowing and fallowing were only used against RYMV and each perceived as not effective and somewhat effective (Table 6). Destruction of wild rice and use of resistant varieties were employed against RYMV and brown spot. The use of resistant varieties was perceived as somewhat effective and effective. The destruction of wild rice on the other hand was perceived as not effective and indifferent. Adjusting fertilizer dosage was used to manage RYMV, leaf blast, panicle blast and bacterial leaf blight, and perceived as somewhat effective, effective and indifferent.

Table 6. Percentage of farmers reporting perceived level of effectiveness of management options against the major diseases

\begin{tabular}{|c|c|c|c|c|c|c|}
\hline Management options & $\begin{array}{l}\text { No. farmers } \\
\text { employing } \\
\text { management } \\
\text { option }\end{array}$ & Diseases employed against & $\begin{array}{l}\text { \% age } \\
\text { perceiving } \\
\text { as not } \\
\text { effective }\end{array}$ & $\begin{array}{l}\text { \% age } \\
\text { perceiving as } \\
\text { somewhat } \\
\text { effective }\end{array}$ & $\begin{array}{l}\% \text { age } \\
\text { perceiving } \\
\text { as effective }\end{array}$ & $\begin{array}{l}\% \text { age } \\
\text { indifferent } \\
\text { about the } \\
\text { effectiveness }\end{array}$ \\
\hline Uprooting diseased plants & 41 & RYMV, LB, BS, ShR, PB and BLB & 24 & 34 & 10 & 32 \\
\hline Insecticide use & 17 & RYMV, LB, BS, ShR, PB and BLB & 24 & 18 & 40 & 18 \\
\hline Early sowing & 2 & RYMV & 50 & 50 & 0 & 0 \\
\hline Fallowing & 2 & RYMV & 50 & 50 & 0 & 0 \\
\hline Burning rice stubble & 12 & RYMV, LB, BS, ShR, PB and BLB & 33 & 33 & 9 & 25 \\
\hline Destruction of wild rice & 3 & RYMV and BS & 33 & 0 & 0 & 67 \\
\hline Use of resistant varieties & 5 & RYMV and BS & 0 & 80 & 20 & 0 \\
\hline Adjusting fertilizer dosage & 7 & RYMV, LB, PB and BLB & 0 & 29 & 57 & 14 \\
\hline
\end{tabular}

Note. RYMV = Rice Yellow Mottle Virus; LB = Leaf Blast; BS = Brown Spot; ShR = Sheath Rot; PB = Panicle Blast; BLB = Bacterial Leaf Blight.

\subsection{Farmers Knowledge on Weeds and Other Vegetation as Alternative Host of Rice Diseases}

The responding farmers provided their views based on observation of symptoms of rice diseases on weeds and or other vegetation in and around rice fields, which are alternative host of rice diseases. Only 23 farmers (10\%) reported noticing rice diseases on weeds/vegetation in and around rice fields. Ten of these farmers $(44 \%)$ were from Northern region, $12(52 \%)$ from Eastern and 1 (4\%) from Central region. The diseases observed on weeds included leaf blast (LB), brown spot (BS), bacterial leaf blight (BLB), sheath blight (ShB), sheath rot (ShR) and 
grain rot (GR). The weeds/vegetation infected by these rice diseases were sedges (Cyperus spp.), goat weed (Ageratum conyzoides), black jack (Bidens pilosa) and cut grass (Leersia spp.). Black jack and goat weed were only infected by brown spot (BS), while cut grass was infected by leaf blast and grain rot. Sedges was infected by all except leaf blast.

\section{Discussion}

The main aim of the study was to establish farmers' knowledge on rice diseases and how they are managing them. Farmers recognized diseases as a main constraint in rice production, second to insect pest, a finding that is in line with Mwalyego and Kayeke (2011), who reported diseases as a major constraint in rice production. Majority of the farmers interviewed identified RYMV, leaf blast, brown spot, sheath rot, panicle blast and bacterial leaf blight, in order of importance, as the most important diseases. This finding is in contrast with the order of importance of diseases by Mwalyego and Kayeke (2011), who reported blast as the most important disease, followed by RYMV, bacterial leaf blight and brown spot. Even though, the order of importance of rice diseases pointed out by the farmers in Uganda varied from that of Mwalyego and Kayeke (2011), the diseases identified as the most important in this study are also the ones pointed by Mwalyego and Kayeke (2011). The importance of a disease is determined by its prevalence and the extent of loss in quantity or quality of the produce, according to Mwalyego and Kayeke (2011), implying the diseases pointed by these farmers cause significant rice yield losses. RYMV being the most important rice disease in Uganda as recorded by this study, is similar to the finding of Abubakar et al. (2003), who reported RYMV as an important disease in most rice growing countries of Africa and Madagascar. Moreover Abo, Sy, and Alegbejo (1998) reported RYMV as a major constraint in rice production due to its wide geographical distribution and the extent of yield losses, where it accounts for $25 \%$ to $100 \%$ loss depending on the varieties grown. Brugidou, Natacha, Yeager, Beachy, and Frauquet (2002) noted RYMV as being responsible for substantial economic losses in rice production throughout Eastern and Western Africa. Traore et al. (2010) also mentioned RYMV as the most important virus disease of rice in Africa.

Leaf blast and panicle blast, respectively, were ranked as the second and fifth most important rice diseases in Uganda, a finding that is in line with Webster (2000), who noted that blast is a fungal disease considered important world-wide due to its wide spread distribution (over 80 countries) as well as its potential to cause up to $50 \%$ yield loss when conditions are favorable for its occurrence. Youyong (2006) reports that blast is a common fungal rice disease that can cause $40-75 \%$ yield loss, and may be called leaf blast, collar rot, node blast, panicle blast or rotten neck blast depending on the infected part of the rice plant. Brown spot was ranked as the third most important rice disease in Uganda, a finding that is consistent with Mwalyego and Kayeke (2011), and who reported brown spot as a fungal disease which is widespread in all rice growing ecologies causing an estimated $12-43 \%$ yield loss, though it can cause up to $100 \%$ yield loss during epidemics. The finding of sheath rot and bacterial leaf blight as some of the important rice diseases in Uganda is also consistent with Mwalyego and Kayeke (2011) who noted sheath rot as a fungal disease that can cause 3-20\% yield loss, and bacterial leaf blight as a bacterial disease that is widespread in all rice growing areas causing yield loss of $20-60 \%$.

The study noted that $60 \%$ of farmers could recognize RYMV while less than $30 \%$ distinctively identified each of the other diseases, an indication that RYMV is an important disease in rice production, as perceived by the farmers. Most of the farmers that are knowledgeable about rice diseases were from Northern and Eastern regions, which could be explained by the fact that these regions had experienced rice production right from the 1950s unlike the Central region where none of its farmers had more than 10 years of experience in rice production. The fact that a greater percentage of farmers were not able to recognize the respective diseases could mean that they are not able to justify whether these diseases are of economic importance or minor. It could also be the reason why less than $30 \%$ of farmers were employing management options against rice diseases. The disease management options employed in rice production included uprooting diseased plants, insecticide use, burning of rice stubble and adjusting fertilizer dosage. The most practiced option across diseases was uprooting diseased plants, which could be as a result of the farmers inability to make proper diagnosis of the diseases, a prerequisite for getting the right control measure. The second predominant control measure was insecticide application, where majority of farmers using this option perceived it as effective. These farmers employed each measure as a distinct management option which contradicts with the recommendation of Mwalyego and Kayeke (2011); integrated rice disease management (IDM). IDM is a combination of different methods (varietal resistance, crop/cultural management techniques and modest use of chemicals), to control diseases in a cost effective way, and based on sound environmental management. However, effective disease management can only be achieved if the capacity of farmers is built in disease symptom identification and IDM. 
The study generated information from farmers regarding weeds/vegetation in and around rice fields that are infested by rice diseases, and which could be alternate hosts for rice diseases. Although only about $10 \%$ of farmers provided this information, the plants mentioned to have been observed as alternate hosts to rice diseases were sedges (Cyperus spp.), goat weed (Ageratum conyzoides), black jack (Bidens pilosa) and cut grass (Leersia spp.). This important information generated from farmers can be validated through research and incorporated into the Integrated Disease Management (IDM) package for rice.

\section{Conclusion}

Improved rice productivity can be achieved through the development and implementation of a sustainable, safe and cost-effective rice disease management strategy. However, the development and implementation process of the strategy should recognize farmers as the primary players in the rice production chain. In addition, the strategy should take into account the findings of the study as a starting point. These findings include (i) Diseases are the second most important constraint in rice production after insect pests (ii) Rice yellow mottle virus is the most important disease in rice production in Uganda (iii) The other diseases of utmost concern in order of their economic importance are leaf blast, brown spot, sheath rot, panicle blast and bacterial leaf blight (iv) Farmers are more knowledgeable about RYMV than any other disease (v) Farmers' knowledge about rice diseases increases with the importance of the disease as well as experience and interactions with the crop (vi) farmers are predominantly managing rice diseases by uprooting diseased plants (vii) Alternate host plants for rice diseases exist in weeds and vegetation in and around rice fields (viii) farmers are predominantly growing rice only for one season of a year (ix) farmers are new entrants in rice production with experience of less than 10 years (xi) rice farmers have attained the lowest level (primary) of formal education.

\section{Acknowledgements}

The study was funded by the East African Agricultural Productivity Project (EAAPP), a World Bank funded project. The data used in the study is from a big study focusing on rice pests and disease knowledge and management in Uganda.

\section{References}

Abo, M. E., Sy, A. A., \& Alegbejo, M. D. (1998). Rice yellow mottle virus (RYMV) in Africa: Evolution, distribution, economic significance on sustainable rice production and management strategies. $J$. Sustainable Agric., 11, 85-11. https://doi.org/10.1300/J064v11n02_08

Abubakar, Z., Fadhila, A., Agnes, P., Oumar, T., Placide, N., Jean-Loup, N., ... Denis, F. (2003). Phylogeography of Rice Yellow Mottle Virus in Africa. J Gen Virol, 84(3), 733-743. https://doi.org/10.1099/vir.0.18759-0

Ahmed, M. (2012). Analysis of Incentives and Disincentives for Rice in Uganda. MAFAP, FAO: Rome, Italy.

Brugidou, C., Natacha, O., Mark, Y., Roger, N. B., \& Claude, F. (2002). Stability of Rice yellow mottle virus and Cellular Compartmentalization during the Infection Process in Oryza sativa (L.). Virology, 297, 98-108. https://doi.org/10.1006/viro.2002.1398

Government of Sindh-Agriculture Department. (2004). Retrieved from http://www.sindhagri.gov.pk/ricedisea.html

Mew, T. W. (1992). Management of rice diseases-A future perspective. In A. Aziz, S. A. Kadir, \& H. S. Barlow (Eds.), Pest management and the Environment (pp. 54-66). Wallingford: CAB International.

Mississippi State University Extension Service. (2001). Rice Diseases in Mississippi: A Guide to Identification. Retrieved from http://msucares.com/pubs/publications/p1840.htm

Mwalyego, F. S., \& Kayeke, J. M. (2011). Important diseases in rice production: Symptoms, damage and management-A guide for farmers. Livelihood improvement through integrated management practices for rainfed lowland ecology.

Odogola, R. W. (2006). Final survey report on the status of rice production, processing and marketing in Uganda. Japan International Cooperation Agency in Collaboration with Sasakawa Africa Association-Uganda

Safdar, A. A., Salahuddin, G., \& Chaudhary, A. R. (1993). Nematode Diseases of Rice in the Punjub Pakistan. Pakistan Journal of Agricultural Research, 14(2\&3). Retrieved from http://www.cabi.org/gara/ FullTextPDF/2009/20093350896.pdf

Traoré, O., Galzi-Pinel, A., Poulicard, N., Hébrard, E., Konaté, G., \& Fargette, D. (2010). Rice yellow mottle virus diversification impact on the genetic control of RYMV. Second Africa Rice Congress, March 22-26, 
2010, Bamako, Mali. Innovation and Partnerships to Realize Africa's Rice Potential. Theme 5: Integrated management of pests, diseases and weeds in rice-based systems.

Webster, R. K. (2000). Department of Plant Pathology, University of California, Davis, USA.

Youyong, Z. (2006). Genetic Diversity for Rice Disease Sustainable Control. The Holeung Ho Lee Foundation. Retrieved from http://www.hlhl.org.cn/english/shownews.asp?newsid=389

\section{Copyrights}

Copyright for this article is retained by the author(s), with first publication rights granted to the journal.

This is an open-access article distributed under the terms and conditions of the Creative Commons Attribution license (http://creativecommons.org/licenses/by/4.0/). 